\title{
TUGAS DAN PERANAN GURU DALAM PROSES PENINGKATAN BELAJAR MENGAJAR
}

\author{
MAULANA AKBAR SANJANI, M. Pd \\ Dosen Prodi Adm. Pendidikan STKIP Budidaya Binjai
}

\begin{abstract}
ABSTRAK
Guru merupakan memegang peranan utama dalam proses belajar mengajar. Proses belajar mengajar merupaka suatu proses yang mengandung serangkaian perbuatan guru dan siswa atau dasar hubungan timbal balik yang berlangsung dalam situasi edukatif untuk mencapai tujuan. Seorang guru memiliki banyak tugas jika dikelompokan tugas guru berupa tugas dalam bidang profesi, tugas kemanusiaan dan tugas dalam bidang kemasyarakatan. Tugas guru dalam proses belajar meliputi tugas paedagogis dan tugas administrasi. Tugas paedagogis merupakan tugas membimbing dan memimpin.
\end{abstract}

Kata Kunci: Guru, BelajarMengajar

\section{PENDAHULUAN}

Guru memiliki tugas yang beragam yang berimplementasi dalam bentuk pengabdian. Tugas tersebut meliputi bidang profesi, bidang kemanusiaan dan bidang kemasyarakatan. Tugas guru sebagai profesi meliputi mendidik, mengajar dan melatih. Mendidik berarti meneruskan dan mengembangkan nilai-nilai hidup dan kehidupan. Mengajar berarti meneruskan dan mengembangkan ilmu pengetahuan dan teknologi. Sedangkan melatih berarti mengembangkan keterampilan-keterampilan pada siswa.

Guru merupakan profesi/jabatan atau pekerjaan yang memerlukan keahlian khusus sebagai guru. Jenis ini tidak bisa dilakukan oleh sembarang orang di luar bidang pendidikan, tetapi pada kenyataannyasekarang ini banyak yang bukan lulusan kependidikan menjadi guru yang seharusnya profesi guru dipegang oleh orang dari lulusan pendidikan.Hal ini dikarenakanorang yang dari non- kependidikan dapat mengambil akta empat dengan leluasa sehingga dapat mengajar disuatu lembaga pendidikan, itu sebabnya sekarang jenis profesi guru ini paling mudah terkena pencemaran karena sembarang orang dapat menjadi guru dan mengajar. 
Kegiatan pembelajaran yang merupakan proses kegiatan belajar dan mengajar, yang terdiri dari guru dan siswa dengan tujuan pematangan intelektual, kedewasaan, emosional, moral dan sebagainya. Relasi antara guru dan siswa dalam proses pembelajaran ini sangat menentukan keberhasilan pembelajaran yang diselenggarakan lembaga pendidikan memerlukan beberapa komponen pendukung agar suasana belajar mengajar bisa mencapai pembelajaran yang efektif.

\section{KAJIAN TEORITIK}

\section{Pengertian Guru}

Karwati dan Priansa(2014:65)

Guru adalah fasilitator utama disekolah,yang berfungsi untuk menggali,mengembangkan,mengoptima lkan potensi yang dimilikinya sehingga menjadi bagian masyarakat yang beradab. Sanjaya (2012: 15) guru merupakan orang yang secara langsung berhadapan dengan siswa, dengan sistem pembelajaran guru dapat berperan sebagai perencana, desainer pembelajaran sebagai implementator atau mungkin keduanya.

Di dalam masyarakat, dari yang paling terbelakang sampai yang paling maju,guru memegang peranan penting. Guru merupakan satu diantara pembentuk-pembentuk utama calon warga masyarakat. Peranan guru tidak hanya terbatas sebagai pengajar (penyampai ilmu pengetahuan), tetapi juga sebagai pembimbing, pengembang, dan pengelola kegiatan pembelajaran yang dapat memfasilitasi kegiatan belajar siswa dalam mencapai tujuan yang telah ditetapkan. Jadi dapat disimpulkan bahwa guru sebagai orang yang bertugas terkait dengan upaya mencerdaskan kedidupan bangsa dalam semua aspeknya melalui mengoptimalan berbagai potensi yang dimiliki oelh peserta didik.

\section{Tugas Guru Dalam Proses Belajar Mengajar}

Sabri (2010:65) Guru merupakan memegang peranan utama dalam proses belajar mengajar. Proses belajar mengajar merupaka suatu proses yang mengandung serangkaian perbuatan guru dan siswa atau dasar hubungan timbal balik yang berlangsung dalam situasi edukatif untuk mencapai tujuan.

Seorang guru memiliki banyak tugas jika dikelompokan tugas guru berupa tugas dalam bidang profesi, tugas kemanusiaan dan tugas dalam bidang kemasyarakatan. Tugas guru dalam proses belajar meliputi tugas paedagogis dan tugas administrasi. Tugas paedagogis merupakan tugas membimbing dan memimpin.

1. Tugas guru sebagai profesi meliputi mendidik, mengajar dan melatih. Mendidik berarti meneruskan dan mengembangkan nilai-nilai hidup. Mengajar berarti meneruskan dan mengembangkan keterampilan keterampilan pada siswa.

2. Tugas guru bidang kemanusiaan disekolah harus dapat menjadikan dirinya sebagai orang tua kedua. Ia harus mampu menarik simpati sehingga ia menjadi idola para siswanya.

Masyarakat menempatkan guru 
sebagai orang yang lebih terhormat dilingkungan karena dari seorang guru diharpkan masyarakat dapat memperoleh ilmu pengetahuan. Tugas guru tidak hanya sebatas didalam masyarakat, bahkan guru pada hakikatnya merupakn komponen strategi yang memilih peran yang penting dalam menentukan gerak maju kehidupan bangsa.

Sabri (2010:68) Sebagai yang dikemukakan diatas perkembangan baru terhadap pandangan belajar mengajar membawa konsekuensi kepada guru untuk meningkatkan peran dan kompetensinya karena proses belajar mengajar dan hasil belajar siswa sebagian besar ditentukan oleh peranan dan kompetensi guru. Adapun peranan guru ialah:

1. Guru sebagai demontrator :guru hendaknya menguasai bahan atau materi pelajaran yang akan diajarkan, serta senantiasa mengembangkan dalam arti meningkatkan kemampuannya dalam hal ilmu yang dimilikinya karena hal ini sangat menentukan hasil belajar yang dicapai oleh siswa.

2. Guru sebagai pengelola kelas. Dalam peran sebagai pengelola kelas, guru hendaknya mampu mengolah kelas sebagai lingkungan sekolah yang perlu di organisir. Lingkungan ini diatur dan diawasi agar kegiatan belajar mengajar terarah kepada tujuan pendidikan. Lingkungan yang baik adalah lingkungan yang menantang danmerangsang siswa untuk belajar, memberikan rasa aman dan kepuasan dalam mencapai lingkungan.

3. Guru sebagai mediator dan fasilitator. Mediator ini dapat diartikan sebagai penengah dalam kegiatan belajar siswa. Misalnya saja menengahi atau memberikan jalan keluar atau solusi ketika diskusi tidak berjalan dengan baik. Mediator juga dapat diartikan sebagai penyedia media pembelajaran, guru menentukan media pembelajaran mana yang tepat digunakan dalam pembelajaran.Guru wajib memberikan fasilitas atau kemudahan dalam proses belajar mengajar misalnya dengan menciptakan susana kegiatan pembelajaran yang kondusif, seerasi dengan perkembangan siswa, sehingga interaksi belajar mengajar berlangsung efektif dan optimal.

4. Guru sebagai evluator Guru memiliki tugas untuk menilai dan mengamati perkembangan prestasi belajar peserta didik. Guru memiliki otoritas penuh dalam menilai peserta didik, namun demikian evaluasi tetap harus dilaksanakan dengan objektif. Evaluasi yang dilakukan guru harus dilakukan dengan metode dan prosedur tertentu yang telah direncanakan sebelum kegiatan pembelajaran dimulai.

5. Peran guru dalam pengadministraasian. Guru sebagai administrator. Seorang guru tidak hanya sebagai pendidik dan pengajar, tetapi juga sebagai administrator pada bidang pendidikan dan pengajaran. Oleh karena itu seorang guru dituntut bekerja secara administrasi teratur. Segala pelaksanaan dalam kaitannya proses belajar mengajar perlu diadministrasikan secara baik. Sebab administrasi yang dikerjakan seperti membuat rencana mengajar, mencatat hasil belajar dan sebagainya merupakan dokumen yang berharga bahwa ia telah melaksanakan 


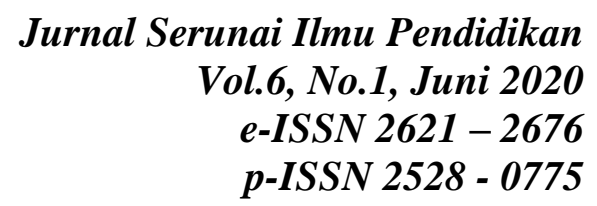

tugasnya dengan baik.

6. Peran guru secara pribadi. Sebagai dirinya sendiri guru harus berperan sebagai: Petugas sosial, Pelajar dan ilmuwan, Orang tua, Teladan, Pengama

7. Peran guru secara psikologis. Sabri (2010: 74). Guru dipandang sebagai ahli psikologi pendidikan, seniman dalam hubungan antara manusia, membentuk kelompok sebagai jalan atau alat pendidikan, catalytic, dan petugas kesehatan mental.

8. Sebagai Motivator, Djamarah (2010: 43) guru hendaknya dapat mendorong peserta didik agar bergairah dan aktif belajar. Dalam upaya memberikan motivasi, guru dapat menganalisi motifmotif yang melatarbelakangi peserta didik malas belajar dan menurun prestasinya di sekolah. Setiap saat guru harus bertindak sebagai motivator, karena dalam interaksi edukatif tidak mustahil ada di Antara peserta didik yang malas belajar dan sebagainya.

\section{Aktivitas Guru Dalam Membelajarkan Peserta Didik}

Guru harus mampu memahami kondisi-kondisi yang memungkinkan dirinya berbuat salah, dan yang paling penting adalah mengendalikan diri serta menghindari dari kesalahan-kesalahan. Ada tujuh kesalahan yang sering dilakukan guru dalam permbelajaran, yaitu ;

1. Mengambil Jalan Pintas Dalam Pembelajaran

Tugas guru paling utama adalah mengajar, dalam pengertian menata lingkungan agar terjadi kegiatan belajar pada peserta didik. Berbagai kasus menunjukan bahwa diatara para guru banyak yang merasa dirinya sudah dapat mengajar dengan baik, meskipun tidak dapat menunjukan alasan yang mendasari asumsi itu.Asumsi keliru tersebut seringkali menyesatkan dan menurunkan kreatifitas, sehinga banyak guru yang suka mengambil jalan pintas dalam pembelajaran, baik dalam perencanaan, pelaksanaan, maupun evaluasi.

Agar tidak tergiur untuk mengambil jalan pintas dalam pembelajaran, guru hendaknya memandang pembelajaran sebagai suatu system, yang jika salah satu komponennya terganggu, maka akan menggangu seluruh system tersebut. Sebagai contoh, guru harus selalu membuat dan melihat persiapan setiap mau melakukan kegiatan pembelajaran., serta merevisi sesuai dengan kebutuhan peserta didik, dan perkembangan zamannya.

Harus selalu diingat mengajar tampa persiapan merupakan jalan pintas, dan tindakan yang berbahaya, yang dapat merugikan perkembangan peserta didik, dan mengancam kenyamanan guru.

2. Menunggu Peserta Didik Berperilaku Negatif

Dalam pembelajaran di kelas, guru berhadapan dengan sejumlah peserta didik yang semuanya ingin diperhatikan. Peserta didik akan berkembang secara optimal melalui perhatian guru yang positif, sebaliknya perhatian yang negative akan menghambat perkembangan peserta didik. Mereka senang jika mendapat pujian dari guru dan merasa kecewa 


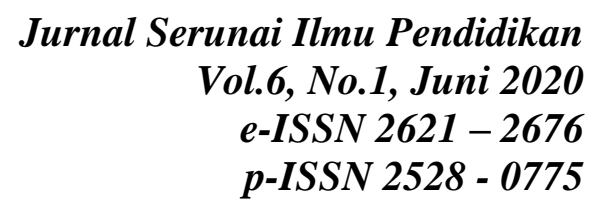

jika kurang diperhatikan .

Namun sayang kebanyakan guru terperangkap dengan pemahaman yang keliru tentang mengajar, mereka menganggap mengajar adalah menyampaikan maateri kepada peserta didik, mereka juga menganggap mengajar adalah memberika pengetahuan kepada peserta didik. Tidak sedikit guru yang sering mengabaikan perkembangan kepribadian peserta didik, serta lupa memberikan pujian kepada mereka yang berbuat baik, dan tidak membuat masalah.

Biasanya guru baru memberikan perhatian kepada peserta didik ketika rebut, tidur dikelas, tidak memperhatikan pelajaran, sehingga menunggu peserta didik berperilaku buruk. Kondisi tersebut sering kali mendapatkan tanggapan yang salah dari peserta didik, mereka beranggapan bahwa untuk mendapatkan perhatian dari guru harus berbuat salah, burbuat gaduh, menganggu atau melakukan tindakan tidak disiplin lainnya. Seringkali terjadi perkelahian pelajar hanya karena mereka tidak mendapatkan perhatian, dan meluapkannya melalui perkelahian. Hasil penelitian menunjukkan bahwa kebanyakan peserta didik tidak tahu bagaimana cara yang tepat untuk mendapatkan perhatian dari guru, orang tua, dan masyarakat sekitarnya, tetapi mereka tahu cara menggangu teman, membuat keributan, serta perkelahian, dan ini kemudian yang mereka gunakan untuk mendapatkan perhatian.

Guru perlu belajar untuk menangkap perilaku positif yang

ditunjukan oleh para peserta didik, lalu segera memberi hadiah atas prilaku tersebut dengan pujian dan perhatian. Kedengarannya hal ini sederhana. tetapi memerlukan upaya sungguh-sungguh untuk tetap mencari dan member hadiah atas perilaku-perilaku positif peserta didik, baik secara kelompok maupun individual.

Menghargai perilaku peserta didik yang postif sungguh memmberikan hasil nyata. Sangat efektif jika pujian guru langsung diarahkan kepada perilaku khusus dari pada hanya diekspresikan dengan pernyataan positif yang sifatnya sangat umum. Sangat efektif guru berkata "termakasih kalian telah mengerjakan

pekerjaan rumah dengan sungguhsungguh" daripada "kalian sangat baik hari ini"

3. Mengabaikan Perbedaan Peserta Didik

Kesalahan berikutnya yang
sering dilakukan guru dalam
pembelajaran adalah mengabaikan
perbedaan individu peserta didik. Kita
semua mengetahui setiap peserta didik
memiliki perbedaan yang sangat
mendasar yang perlu diperhatikan
dalam pembelajaran. Peserta didik memiliki emosi yang sangat bervariasi, dan sering memperlihatkan sejumlah perilaku yang tampak aneh. Pada umumnya perilaku-perilaku tersebut cukup normal dan dapat ditangani dengan menciptakan pembelajaran yang kondusif. Akan tetapi karena guru disekolah dihadapkan pada sejumlah peserta didik, guru seringkali sulit untuk membedakan mana perilaku yang wajar atu normal dan mana perilaku yang indisiplin dan perlu penanganan 


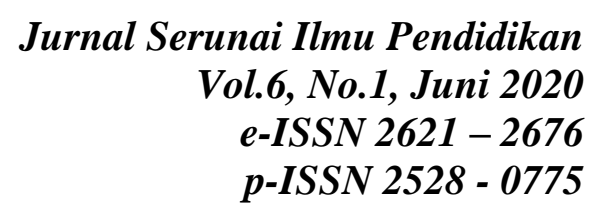

khusus.

Setiap peserta didik memiliki perbedaan yang unik, mereka memiliki kekuatan, kelemahan, minat, dan perhatian yang berbeda-beda. Latar belakang keluarga, latar belakang social ekonomi, dan lingkungan, membuat peserta didik berbeda dalam aktifitas, kreatifitas, intlegensi, dan kompetensinya. Guru seharusnya dapat mengidentifikasi perbedaan individual peserta didik, dan menetapkan karakteristik umum yang menjadi cirri kelasnya, dari ciri-ciri individual yang menjadi karakteristik umumlah seharusnya guru memulai pembelajaran. Dalam hal ini, guru juga harus memahami ciri-ciri peserta didik yang harus dikembangkan dan yang harus diarahkan kembali.

4. Merasa Paling Pandai

Kesalahan lain yang sering dilakukan guru dalam pembelajaran adalah merasa paling pandai dikelas. Kesalahan ini berangkat dari kondisi bahwa pada umumnya para peserta didik disekolahnya relative lebih muda dari gurunya, sehingga guru merasa bahwa peserta didik tersebut lebih bodoh disbanding dirinya, peserta didik dipandang sebagai gelas yang perlu di isi air ke dalamnya. Perasaan ini sangat menyesatkan karena dalam kondisi seperti sekarang ini peserta didik dapat belajar melalui internet dan berbagai media massa, yang

mungkin guru belum menikmatinya.

5. Diskriminatif

Pembelajaran yang baik dan efektif adalah yang mampu memberi kemudahan belajar secara adil dan merata (tidak diskriminatif), sehingga peserta didik dapat mengembangkan potensinya secara optimal. Keadilan dalam pembelajaran meupakan kewajiban guru dan hak peserta didik untuk memperolehnya. Dalam prakteknya banyak guru yang tidak adil, sehingga merugikan perkembangna peserta didik, dan ini merupakan kesalahan guru yang sering dilakukan, terutama dalam penilaian. Penilaian merupakan upayakan untuk memberikan penghargaan kepada peserta didik sesuai dengan usaha yang dilakukannya selama proses pembelajaran.

6. Memaksa hak peserta didik

Memaksa hak peserta didik merupakan kesalahan yang sering dilakukan guru, sebagai akubat dari kebiasaan guru berbisnis dalam pembelajaran, sehingga menghalalkan segala cara untuk mendapatkan keuntungan. Guru boleh saja memiliki pekerjaan sampingan, memperoleh penghasilan tambahan, itu sudah menjadi haknya, tetapi tindakkan memaksa bahkan mewajibkan peserta didik untuk membeli buku tertentu sangat fatal serta kurang bisa digugu dan ditiru. Sebatas menawarkan boleh saja, tetapi kalau memaksa kasihan bagi orangtua yang tidak mampu.

Sedangkan menurut Hamruni (2012: 23) menyebutkan ada 4 kekeliruan dalam proses belajar mengajar yang dilakukan oleh guru yaitu :

1. Ketika mengajar, guru tidak berusaha mencari informasi, apakah materi yang diajarkannya sudah dipahami oleh siswa atau belum. 


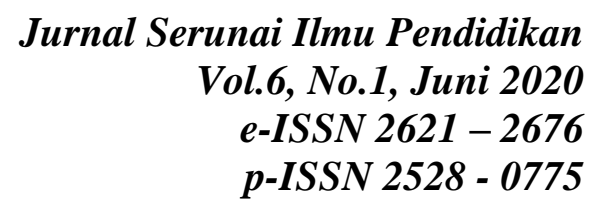

2. Dalam proses belajar mengajar guru tidak berusaha mengajak berpikir kepada siswa. Komunikasi bisa terjadi satu arah, yaitu dari guru ke siswa. Guru menganggap bahwa bagi siswa menguasai materi pelajaran lebih penting dibandingkan dengan mengembangkan kemampuan berpikir.

3. Guru tidak berusaha mencari umpan balik mengapa siswa tidak mau mendengarkan penjelasannya.

4. Guru menganggap bahwa ia adalah orang yang paling mampu dan menguasai pelajaran dibandingkan dengan siswa.

\section{PEMBAHASAN}

Sebagai seorang pendidik yang memahami fungsi dan tugasnya, guru khususnya ia dibekali dengan berbagai ilmu keguruan sebagai dasar, disertai pula dengan seperangkat latihan keterampilan keguruan dan pada kondisi itu pula ia belajar memersosialisasikan sikap keguruan yang diperlukannya. Seorang yang berpribadi khusus yakni ramuan dari pengetahuan sikap danm keterampilan keguruan yang akan ditransformasikan kepada anak didik atau siswanya. Guru yang memahami fungsi dan tugasnya tidak hanya sebatas dinding sekolah saja, tetapi juga sebagai penghubung sekolah dengan masyarakat yang juga memiliki beberapa tugas menurut Rostiyah dalam Djamarah (2010 : 36) mengemukakan bahwa fungsi dan tugas guru profesional adalah : Menyerahkan kebudayaan kepada anak didik berupa kepandaian, kecakapan dan pengalaman-pengalaman Membentuk kepribadian anak yang harmonis sesuai cita-cita dan dasar negara kita.
Peranan guru dalam mengajar sangatlah penting karena guru sebagai pemimpin pembelajaran yang mengarahkan dan memainkan peranan yang berarti bagi siswa dalam pengemabangan intelektualnya. Guru yang disebut mampu berhasil dalam belajar mengajar adalah guru yang memiliki kompetensi sebagai guru yaitu paedagogik, profesional, kepribadian dan sosial.

Proses pembelajaran ataupun kegiatan belajar-mengajar tidak bisa lepas dari keberadaan guru. Tanpa adanya guru pembelajaran akan sulit dilakukan, apalagi dalam rangka pelaksanaan pendidikan formal, guru menjadi pihak yang sangat vital. Guru memiliki peran yang paling atif dalam pelaksanaan pendidikan demi mencapai tujuan pendidikan yang hendak dicapai. Guru melaksanakan pendidikan melalui kegiatan pembelajaran dengan mengajar peserta didik atau siswa.

Keberhasilan pembelajaran salah satu pendukungya adalah dengan tersedianya media pembelajaran. Karena dengan media pembelajaran akan lebih memperjelas dan lebih memperdalam pemahaman siswa. Pembelajaran kreatif menuntut guru untuk merangsang kreatifitas siswa, baik dalam mengembangkan kecakapan berpikir maupun dalam melakukan suatu tindakan. Berpikir kreatif selalu dimulai dengan berpikir kritis, yakni menemukan dan melahirkan sesuatu yang sebelumnya tidak ada atau memperbaiki sesuatu.

Tidak sulit untuk dipungkiri bahwa peranan guru sebagai pengajar sering diambil salah pengertian, 
seringkali dianggap salah arti, karena mayoritas guru yang menggunakan peranannya disertai dengan keegoisan dalam bertindak sebagai pengajar, seperti menganggap dirinya paling pandai, memberi tugas diluar kemampuan siswa, dll. Hal itu akan mengakibatkan dampak negatif bagi siswa pada pengalaman belajarnya seperti mengalami stress, bosan bahkan sering $\mathrm{x}$ siswa kehilangan motivasi belajarnya sehingga hasil belajar yang ingin dicapai sulit tuk diraih baik oleh guru maupun siswa.

Untuk menghindari kesalahankesalahan guru sebagai pengajar, maka dari itu guru memperbanyak wawasan pengetahuan tentang peran guru dan wawasan tentang siswa ssebagai manusia yang terdidik. Pembelajaran bila berorientasi pada guru dan utamanya pada anak didik maka pembelajaran akan bersifat efektif. Sebagaiman Sagala (2012: 56) rooijakkers menjelaskan bahwa keberhasilan seorang pengajar akan terjamin jika pengajar itu dapat mengajak para murid mengerti suatu masalah melalui semua tahap proses belajar karena dengan cara itu murid akan memahami hal yang diajarkan.

\section{KESIMPULAN}

Guru merupakan memegang peranan utama dalam proses belajar mengajar. Proses belajar mengajar merupaka suatu proses yang mengandung serangkaian perbuatan guru dan siswa atau dasar hubungan timbal balik yang berlangsung dalam situasi edukatif untuk mencapai tujuan.
Seorang guru memiliki banyak tugas jika dikelompokan tugas guru berupa tugas dalam bidang profesi, tugas kemanusiaan dan tugas dalam bidang kemasyarakatan. Tugas guru dalam proses belajar meliputi tugas paedagogis dan tugas administrasi. Tugas paedagogis merupakan tugas membimbing dan memimpin.

\section{DAFTAR PUSTAKA.}

Djamarah, SB. (2010). Gurudan Anak Didik dalam Interaksi Edukatif. Jakarta: Asdi Mahasatya.

Hamruni. (2012). Strategi Pembelajaran. Yogyakarta: Insan Madani.

Karwati, E. dan Priansa, D. J. (2014). Manajemen Kelas (Classroom Management) Guru Profesional Yang Inspiratif, Kretatif, Menyenangkan Dan Berprestasi. Bandung: Alfabeta.

Sabri, H. A. (2010). Strategi Belajar Mengajar Dan Micro Teaching. Ciputat: Quantum Teaching.

Sagala. H. S. (2012). Supervisi Pembelajaran Dalam Profesi Kependidikan.Bandung: Alfabeta.

Sanjaya, H. W. (2012). Perencanaan dan Desain Pembelajaran. Jakarta: Kencana. 